\title{
OUVINDO RELIGIOSAMENTE A PALAVRA DE DEUS A ESCUTA A PARTIR DO PROÊMIO DA DEI VERBUM
}

Elcio Rubens Mota Felix*

\begin{abstract}
RESUMO
O presente artigo tratará sobre a escuta da Palavra de Deus. O ponto de partida desta reflexão é o proêmio da Constituição dogmática Dei Verbum. A afirmação, "ouvindo religiosamente a Palavra de Deus”, está presente na Constituição dogmática e agora faz parte do objeto de nossa reflexão. A finalidade, portando, de toda pesquisa é o estudo desta afirmação, junto com a necessária elaboração dos elementos bíblico-teológicos que vão dar fundamentos à citada afirmação: "ouvindo religiosamente a Palavra de Deus". Por fim, o Cristo será apontado como o novo
\end{abstract} Moisés e como modelo de escuta.

Palavras-Chave: Escuta. Dei Verbum. Fundamentos bíblico-teológicos. Jesus Cristo.

\begin{abstract}
The present article will deal about listening to the Word of God. The starting point of this reflection is the prologue of the Dogmatic Constitution Dei Verbum. The statement, "listening religiously the Word of God," is present in the Dogmatic Constitution and is now part of the object of our reflection. The purpose, therefore, of all research is the study of this statement, along with the necessary preparation of biblical and theological elements that will give grounds to the above statement: "listening religiously the Word of God". Finally, the Christ will be appointed as the new Moses and a model of listening.
\end{abstract}

Keywords: Listening. Dei Verbum. Biblical and theological foundations. Jesus Christ.

\footnotetext{
* Sacerdote da Congregação dos Sagrados Corações. Mestrando em Teologia Dogmática pela Pontifícia Universidade Católica de São Paulo.
} 


\section{INTRODUÇÃO}

Iniciamos nossa reflexão, lembrando o proêmio da Constituição Dogmática ${ }^{1}$ Dei Verbum, do Concílio do Vaticano II:

O sagrado Concílio, ouvindo religiosamente a Palavra de Deus proclamando-a com confiança, faz suas as palavras de $S$. João: "anunciamos-vos a vida eterna, que estava junto do Pai e nos apareceu: anunciamo-vos o que vimos e ouvimos, para que também vós vivais em comunhão conosco, e a nossa comunhão seja com o Pai e com o seu Filho Jesus Cristo" (1Jo. 1,2-3). Por isso, segundo os Concílios Tridentino e Vaticano I, entende propor a genuína doutrina sobre a Revelação divina e a sua transmissão, para que o mundo inteiro, ouvindo, acredite na mensagem da salvação, acreditando espere, e esperando ame (DV 1).

Mais do que uma afirmação conciliar de um documento de grande relevância, esta afirmação, ouvindo religiosamente a Palavra de Deus, é, sobretudo, a autoconsciência de uma identidade. Isto é, o reconhecimento de que, na estrutura ontológica da Igreja (no seu ser), em primeiro lugar, está a escuta da Palavra de Deus. É somente a partir da "escuta" da Palavra de Deus que podemos nos lançar à sua proclamação. $\mathrm{O}$ "ouvindo religiosamente" merece, com efeito, estudo e reflexão, devido o lugar que ocupa no conjunto do documento, já que todo o Concílio, isto é, os padres conciliares, devem em primeiro lugar, escutar a Palavra de Deus. E é somente a partir desta atitude que se pode debruçar nos demais empreendimentos. ${ }^{2}$ É a partir da

1 SCHOKEL, Alonso. Comentário sobre a Constituição Dogmática Dei Verbum. BAC, p. 125. É Constituição Dogmática porque promulga doutrina: Distingue-se dos decretos e declarações e também de uma constituição pastoral como a Igreja no mundo atual (GS) - outro texto interessante sobre o mesmo assunto e com a mesma visão nós o encontramos assim: é Constituição porque é reservada para textos que expõem e discutem verdades doutrinais e é dogmática porque a eleva a máxima importância como doutrina que tem valor normativo para a fé da Igreja, cf. SILVA, Cássio Murilo Dias da. O Impulso bíblico no Concílio: A Bíblia na Igreja depois da Dei Verbum. In: Teocomunicação, Porto Alegre/ Brasil: Edição PUC-RS, vol. 36, n. 151, p. 28, mar., 2006; esta Constituição conciliar foi um dos documentos de redação mais difíceis do Concílio, por ter sido o que mais tempo demorou para sua aprovação final. Iniciara sua discussão a 14 de novembro de 1962 e sua promulgação somente aconteceria a 18 de novembro de 1965.

2 Estes empreendimentos se referem sobre a elaboração dos demais documentos e das árduas discussões travadas nas sessões ao longo do Concílio. Cf. KLOPPENBURG, Boaventura. Concílio Vaticano II. Vol. II. Petrópolis: Vozes, 1963, p. 168-193. 
escuta da Palavra de Deus que os padres do Concílio, em seguida, vão se por na tarefa de elaborar a autentica doutrina sobre a Revelação de Deus e todos os outros documentos. Diz a Dei Verbum, que o Concílio pretende propor uma autentica doutrina da Revelação de Deus e sua transmissão. A Constituição Dogmática Dei Verbum começa com a afirmação "ouvindo religiosamente a Palavra de Deus": tal afirmação sustenta todo o restante do documento, sem a qual não seria possível ir adiante. Para tanto, é necessário elaborar os fundamentos que deságuam nesta afirmação conciliar. E tal afirmação é como uma herança. ${ }^{3}$ Sendo dois os fundamentos: o bíblico e o teológico. O "ouvindo religiosamente a Palavra de Deus", possui uma base bíblica além de uma raiz teológica. Somente assim, elaborando estes dois fundamentos, obteremos uma visão mais profunda e correspondente à Constituição Dei Verbum. ${ }^{4}$

Nosso trabalho, no primeiro momento, situará o "ouvindo religiosamente a Palavra de Deus", ${ }^{5}$ no contexto da Constituição da Dei Verbum. De modo que esta afirmação possa ser compreendida dentro e somente nos limites do documento conciliar. Sem esta premissa não será possível avançar. 0 ouvindo religiosamente a Palavra de Deus se dá no contexto de um Concílio, e este, num âmbito maior de sociedade, de mundo e cultura. Além disto, qual o sentido ou o significado do "ouvindo religiosamente"?

No segundo momento nos deteremos à Sagrada Escritura, sugerindo uma base bíblica para o "ouvindo religiosamente a Palavra de Deus". Esta afirmação está inserida no contexto de Povo de Deus da bíblia. Mesmo sendo um texto elaborado no século $X X$, há de se reconhecer que o "ouvindo religiosamente a Palavra de Deus" é parte inerente de um "modus vivendis"

3 Quero aqui dizer que devemos compreender o tema herança como tradição. O que recebemos ou o que nos foi herdado.

4 LYONNET, Stanislau. A Bíblia na Igreja após a "a Dei Verbum". São Paulo: Paulinas, p. 9. O exegeta, Cardeal Florit, segundo seu parecer, apontava os maiores méritos da Dei Verbum e assim relata: "é uma das mais breves entre as promulgadas pelo Concílio, mas ao tempo uma das mais ricas em doutrina e ainda a coloca no coração do mistério da Igreja e no centro do ecumenismo".

5 Há pouco tempo atrás era publicado pela CNBB, Estudos da CNBB, n. 91. Ouvir e proclamar a palavra: seguir Jesus no caminho. A catequese sob a inspiração da Dei Verbum. São Paulo: Paulus 2006, p. 141. Este estudo é resultado do VII encontro bíblico-catequético Nacional. É um estudo simples, mas muito interessante que vai tratar, especialmente, em grande parte, da mesma questão abordada no presente trabalho: sobre a escuta. Porém, numa perspectiva catequética. 
(modo de viver) de um povo. E este povo é o povo de Deus bíblico. O "ouvindo religiosamente a Palavra de Deus" reflete as tradições bíblicas numa dimensão ampla e às tradições do êxodo num contexto particular. Com isto, queremos adotar, como base bíblica do "ouvindo a Palavra de Deus", as tradições do Êxodo.

Associado a fundamentação bíblica, identificaremos alguns fundamentos teológicos desta afirmação. Que discurso teológico corresponde ao ouvindo religiosamente a Palavra de Deus? Sem uma fundamentação teológica é impossível a compreensão correta que os padres do Concilio quiseram dar na abertura da Dei Verbum.

\section{OUVINDO RELIGIOSAMENTE A PALAVRA DE DEUS}

Nosso estudo será restrito apenas à primeira parte do proêmio da Dei Verbum. O nosso objetivo é o estudo da dimensão da escuta para a vida cristã, de sua importância para a fé. Por isto o foco no "ouvindo religiosamente a Palavra de Deus", que dá sentido a todo o texto. Por hora vamos recordar o que está no proêmio do documento conciliar: "O sagrado Concilio, ouvindo religiosamente a Palavra de Deus".

O "ouvindo religiosamente" é a parte central no proêmio, na abertura deste documento. Vamos nos deter inicialmente na palavra: ouvindo. A palavra "ouvindo" é um verbo. ${ }^{6}$ Significa uma ação sem término; indica ação no presente sem interrupção. ${ }^{7}$ Associada ao "religiosamente", ${ }^{8}$ eleva sua importância, pois enfatiza um modo de ser. Portanto, o ouvindo religiosamente é uma atitude, um modo de ser. É uma adesão pela fé, sobretudo é uma "adesão à Palavra de Deus. Por isso, o proêmio é bastante "enfático,

6 CEgAlLA, Domingos Paschoal. Nova Minigramática da Língua Portuguesa. São Paulo: Companhia Editora Nacional, 3. ed. 2008, p. 145. Ouvindo é gerúndio. Que significam formas nominais do verbo. Tais formas enunciam simplesmente um fato; também verificar: CUNHA, Celso Ferreira da. Gramática da Língua Portuguesa. Rio de Janeiro: FAE, 1992, p. 461-462. Celso Cunha diz que o gerúndio pode ser de forma simples ou de forma composta. No nosso caso, 'ouvindo' é a forma simples e expressa uma ação em curso, que pode ser imediatamente anterior ou posterior à do verbo da oração principal, ou contemporânea dela.

7 Ibidem CUNHA, Celso Ferreira da. p. 462.

8 CEGALLA, p. 201. Na língua português é advérbio. Advérbio é uma palavra que modifica o sentido do verbo, do adjetivo ou do próprio advérbio. 
sobretudo é solene". 9 Com razão o texto fala do Sagrado Concílio na primeira pessoa, colocando-se como que o primeiro "ouvinte", os que devem primeiramente "escutar a Palavra de Deus".10

Já a palavra, religiosamente, acaba reforçando ainda mais a nobreza do "ouvindo". Assim, a escuta assume um caráter de identidade. Religiosamente está ligado ao âmbito religioso. Trata-se essencialmente de um "problema religioso".11 Os padres conciliares são os representantes da Igreja católica no mundo inteiro. O Concílio Vaticano II foi um dos maiores eventos eclesiais dos últimos séculos afirmam alguns estudiosos. ${ }^{12}$ Quando na Dei Verbum encontramos a afirmação de que o Sagrado Concílio se põe à escuta da Palavra de Deus, devemos entender que é toda a Igreja que deve se colocar à escuta. Todos os que são igreja devem se por numa dócil escuta da Palavra de Deus.

\section{O CONTEXTO CONCILIAR}

\subsection{A Assembleia Conciliar}

Passados três meses de sua eleição, o papa João XXIII anunciava o desejo de realizar um Concílio (25/01/1959). ${ }^{13}$ A intenção de convocar um Concílio era inspirada em outras grandes assembleias, como bem lembraria na abertura do mesmo Concilio. ${ }^{14}$ João XXIII recordava com veemência várias assembleias que ocorreram ao longo da História da Igreja, mas especialmente de Pentecostes. ${ }^{15}$ Para João XXIII, o caminho

9 PIAZZA, Waldomiro O. A revelação cristã: na constituição dogmática "Dei Verbum". São Paulo: Loyola, 1986, p.36. Outros autores compartilham da mesma visão: Para ver outras visões sobre o proêmio, cf. LATOURELLE, René. Teologia da Revelação. São Paulo: Paulinas, 1981, p. 369. Também cf. ALONSO Schokel, Luis (dir.). Concilio Vaticano II: comentarios a la constitución Dei Verbum sobre la divina revelación. Madrid: BAC, 1969, p. 133.

10 LATOURELLE, René. Teologia da Revelação. São Paulo: Paulinas, 1981, p. 369-370.

11 PIAZZA, Waldomiro O. A revelação cristã: na constituição dogmática "Dei Verbum". São Paulo: Loyola, 1986, p. 36.

12 ANJOS, Gonzalo Tejerina (coord.). Vaticano II. Acontecimiento y recepción. Estudios sobre El Vaticano II a los cuarenta años de su clausura. Universidad Pontificia de Salamanca, 2006, p. 9. O autor em questão diz que o Vaticano II foi um dos maiores eventos eclesiais de todos os tempos.

13 Documentos do Concílio Ecumênico Vaticano II. São Paulo: Paulus, 2004, p. 14.

14 Ibidem, p. 21.

15 Ibidem, p. 32. 
que ele estava abrindo, deveria ser outro Pentecostes. Quando toda a comunidade dos discípulos de Jesus, juntamente com Maria sua mãe, se punha em oração (Mt 14,13; 26,36), obedientes a Jesus que lhes pedira que permanecessem em Jerusalém, até que fossem revestidos da força do alto (Lc 24,49). O Novo papa comparava o Concílio a outro Pentecostes. É com este contexto de assembleia que situamos o "ouvindo religiosamente a Palavra de Deus", porque, quem deve escutar a Palavra de Deus não é somente os padres do Concílio, mas toda a Igreja. E para elaborar e redigir uma doutrina da revelação de Deus, antes é preciso dar-se à escuta da Palavra. Não somente o papa ou um grupo, mas todo o Concílio, isto é, toda a Igreja.

\subsection{O Contexto da Assembleia Conciliar}

Num contexto mais amplo, a assembleia conciliar no início de tudo, assume como propósito escutar o mundo, dialogar com a sociedade. João XXIII se inspirava na "escuta dos sinais dos tempos", ${ }_{16}^{16}$ que o próprio Jesus exortava no Evangelho (Mt 16,3), isto é, a necessidade de observar os sinais dos tempos. Sem distrações, o papa fala dos sinais dos tempos e assim convocaria o Concílio. Foi escutando os sinais dos tempos que João XXIII adquiriu convicção da urgência e da necessidade da convocação de um Concílio. Ademais, era premente desenvolver o diálogo com a sociedade moderna, com a ciência. ${ }^{17} \mathrm{O}$ diálogo se fazia inevitável e, um diálogo frutuoso e fecundo dependeria antes de tudo da escuta. Como dialogar com estes diversos seguimentos? ${ }^{18}$ Verificamos que foi por causa da escuta, que a Igreja do Vaticano II inclinou-se ou deu passos no tocante ao diálogo. E é bem possível dizer que seja por isso que a Dei Verbum, logo em sua abertura, pôde proclamar a escuta como o modo de ser da Igreja e de seu estatuto ontológico, sempre tomando como princípio a escuta da Palavra de Deus.

16 Ibidem, p. 10.

17 LIBANIO, João Batista. Concilio vaticano II. Em busca de uma primeira Compreensão. São Paulo: Loyola, 2005, p. 71-72.

18 Refiro-me a seguimentos das diversas instâncias no mundo, como a sociedade, a ciência e outras denominações religiosas que o papa João XXIII deseja desenvolver relação.

164 Revista de Cultura Teológica - v. 20 - N. 77 - JAN/MAR 2012 


\section{OS FUNDAMENTOS BÍBLICO-TEOLÓGICOS DO "OUVINDO RELIGIOSAMENTE A PALAVRA DE DEUS"}

\subsection{O Povo de Deus da Bíblia}

O Povo de Israel reconhecia a importância da escuta. Prezavam com zelo e estima a escuta de Deus. Em vários textos, ${ }^{19}$ escutar é também entendido como ouvir e a fidelidade a Deus dependia certamente dessa atitude (escuta de Deus). O Povo semita de modo geral, desde suas origens, especialmente o povo de Israel, era um povo dado à escuta. Por serem povos nômades, pautavam suas tradições pela tradição oral. Sua riqueza de tradição era transmitida oralmente, de geração em geração. Por ser uma cultura de tradição oral, a escuta era essencial para sua manutenção. Também para os povos semitas, especialmente para o povo de Israel, a manutenção da sua tradição, da experiência de fé, da perpetuação e garantia de sua memória, era associada à escuta.

A Revelação de Deus é essencialmente uma verdade revelada pela escuta. O próprio São Paulo nos atesta isso, já nos tempos de Novo Testamento, dirigindo-se à comunidade de Roma, Paulo diz: "a fé nasce da audição". ${ }^{20}$ É importante salientar que a escuta é relevante para a cultura Israelita, tanto quanto o "ver" para a cultura grega. Para os israelitas, o ato de escutar Deus é importante por causa da fé e na cultura grega por causa da filosofia. ${ }^{21}$ A própria Palavra de Deus em si, antes de ser "escrita", foi transmitida através da tradição oral. De geração em geração as verdades de fé foram transmitindas as. É nesse contexto que se deve conciderar a relevância da escuta, do seu alcance e magnitude como atitude fundamental para a preservação das verdades de Fé.

\footnotetext{
19 São diversos os textos, que desenvolvem o tema: Escuta, povo meu, pois te admoesto, Israel, oxalá me escutastes (SI 81,9); vou escutar o que Deu diz (SI 85,9); agora, Israel, escuta os mandamentos e decretos que eu vos ensino a praticar (Dt 4,1); fala, pois teu servo escuta (1Sm 3,10); o meu filho amado escute-o (Mt 17,5); a multidão se comprimia ao redor de Jesus para escutar a Palavra de Deus (Lc 5,1); esse discurso é bem duro: quem poderá escutá-lo? (Jo 6,60); Jesus diz a Pilatos: quem está a favor da verdade escuta minha voz (Jo 18,37).

$20 \operatorname{Rm~10,17.~}$

21 LÉON-DUFOUR, Xavier (dir.). In: Vocabulário de Teologia Bíblica, Petrópolis: Vozes, 2005, p. 688.
} 


\subsection{As Tradições do Êxodo}

As tradições do êxodo têm como cento a experiência de libertação da terra da escravidão no Egito. Na Sagrada Escritura, as tradições do Êxodo se estendem do Livro do Êxodo até o Deuteronômio. Encontramos, nas "tradições do êxodo", 22 o povo de Israel que foi libertado da escravidão e, no deserto, aprendeu a escutar e confiar no Deus único e verdadeiro. E se nas origens do povo de Deus está essencialmente às tradições do êxodo, tanto a experiência de libertação do Egito como a experiência vivida no deserto, então podemos inferir que a escuta tem haver, na sua mais tenra origem, a relação entre libertação, a do Egito e a do Sinai (adoração a Javé, Lei, monte). Ainda se diz que o êxodo do povo de Israel é uma "experiência fundante" 23 e, por isso, a escuta está inserida nesta experiência. Faz parte! Assim, escutar Deus tornou-se vital para a fidelidade do povo de Israel ao longo de sua história e até nos tempos atuais, para o povo de Deus (Israel) e para nós cristãos. O Ser humano é chamado a escutar Deus, e dessa atitude fazê-la uma constante "escuta Israel". ${ }^{24}$

O ser humano, porém, na sua liberdade não quis escutar a Deus. ${ }^{25}$ Disto advém toda a angústia humana, ao se fechar a Deus fecha seus ouvidos, que significa também, fechar o coração, fechar-se a Deus. "Ensurdecer-se aos apelos de Deus". ${ }^{26}$ No Primeiro Testamento, são dignos de nota os textos que fazem referência à escuta. $O$ texto bíblico do êxodo relata com eloquência que é Deus mesmo quem primeiro escuta. ${ }^{27}$ Percebemos que o primeiro a revelar a importância da escuta é o Senhor Deus, quando escuta o grito do seu povo. Um Deus que ouve (escuta) o clamor e a aflição do seu povo, na terra da escravidão. E desta escuta, desce para libertá-los.

\footnotetext{
22 Há diversas obras que citam o tema tradições bíblicas, citamos algumas. SCHWANTES, Milton. História de Israel (local e origens), São Leopoldo, 1984. (Polígrafo). Outra obra: SCHWANTES, Milton (et alii). A memória popular do Éxodo. Petrópolis: Vozes, 1988. Estudos Bíblicos, n. 16. A memória popular do Êxodo. Petrópolis: Vozes, 1988. E por último, FABRIS, Rinaldo (org.). Problemas e Perspectivas das Ciências Bíblicas. São Paulo: Loyola, 402.

${ }^{23}$ SCHWANTES, Milton (et alii). A memória popular do Êxodo. Petrópolis: Vozes, 1988, p. 13 Estudos Bíblicos, n. 16.

24 Dt 6,4.

25 Dt $18,16-19$.

$26 \mathrm{Jr} 6,10$.

27 Ex 3.7.
}

166 Revista de Cultura Teológica - v. 20 - N. 77 - JAN/MAR 2012 
O Êxodo é por excelência o livro de um Deus que escuta seu povo e os liberta. Porque ouve liberta! Liberta porque ouve.

O Senhor leva seu povo para o deserto, não para tentá-los, mas para ensiná-los. Ainda nos primeiros dias, já no deserto e após dias de sede em Mara, ${ }^{28}$ murmuram a Moisés e o Senhor Ihes responde: "se de fato escutares a voz do Senhor teu Deus, se fizeres o que é reto aos seus olhos, se prestares atenção a seus mandamentos e observares todas as suas leis, não te causarei nenhuma das enfermidades que causei aos egípcios, pois eu sou o Senhor que te cura". ${ }^{29}$

Tudo isso, já é uma prova do que vai significar o longo processo de caminho rumo à terra prometida, que antes passa pelo deserto. É ali no deserto que o Senhor Deus educa seu povo a escutar. É nas duras provas da privação de água, comida e outras necessidades ${ }^{30}$ que o povo aprende a duras penas a escutar Deus, sua Palavra. Não faltaram as "murmurações". A raiz da palavra "murmurar" perpassa a caminhada da passagem do povo de Deus pelo deserto. ${ }^{31}$ É nesta experiência de deserto adentro, que é gerado um dos mais profundos mistérios do povo de Deus bíblico: de um Deus que escuta o sofrimento de um povo e um povo que aprende a escutar seu Deus. ${ }^{32}$ Há neste mistério uma experiência fontal, de que a fé israelita se fundamenta "justamente porque no grito dos oprimidos encontra seu centro: Gritamos ao Senhor, o Deus de nossos pais, e o Senhor escutou nossa voz. Ainda afirma o autor: "pois a decisão de gritar ao Senhor causa esperança, pois foi justamente o grito ouvido por Deus que deu origem ao êxodo". ${ }^{33}$

As "tradições do êxodo" estão no plural. Porque existem diversas tradições que sempre remetem à mesma experiência do êxodo, como o "êxodo-aliança, que constituem o coração da tradição do Antigo Testamento $^{34}$ ou das tradições inseridas no contexto literário do Pentateuco, como a

\footnotetext{
28 FERnANDES, L. A; GRENZER, M. Êxodo 15,22 - 18,27. São Paulo: Paulinas, 2011, p. 11.

29 Ex 15,26.

30 Ibidem, p. 11-12.

31 Ibidem, p. 15.

32 Ibidem, p. 16.

33 Ibidem, p. 16.

34 FABRIS, Rinaldo (org.). Problemas e Perspectivas das Ciências Bíblicas. São Paulo: Loyola 2008, p. 7.
} 
"tradição profética". ${ }^{35}$ Toda e qualquer tradição é oriunda da tradição oral, pois as fontes escritas veiculam a "tradição oral". ${ }^{36} \mathrm{O}$ Pentateuco, portanto, é composto em base a quatro documentos: Javista $(J)$, Eloísta $(E)$, Sacerdotal $(P)$ e Deuteronomista (D), ${ }^{37}$ admitindo, além disso, que o Pentateuco foi composto por quatro documentos escritos por pessoas e em diferentes épocas. ${ }^{38}$ Certamente, os autores destes documentos seguem a hipótese documentária e prevê que o conteúdo chegou à suas mãos por meio da "tradição oral" ${ }^{39}$ Levando em conta o "tradições" no plural, há também outras tradições como as "tradições do Sinai", ${ }^{40}$ a "tradição dos patriarcas". ${ }^{41}$ Porém, é necessário afirmar que na "base das tradições orais do Pentateuco, num primeiro grupo, estão: $\mathrm{Gn}, \mathrm{Ex}, \mathrm{Lv}, \mathrm{Nm}$ e num segundo grupo: Dt, Js, 1 e $2 \mathrm{Sm}, 1$ e $2 \mathrm{Rs}^{\prime \prime}{ }^{42}$

No tempo dos profetas já se fazia referência direta à tradição do êxodo (Os 11,1; Jr 2,6; Deutero-Isaías 55,12). ${ }^{43}$ Não foram os profetas os únicos que fizeram tal referência, mas outros grupos o fizeram, aliás, houve grupos que de certa forma, foram os portadores da experiência libertadora do êxodo, conforme atesta alguns estudos. Podemos "deduzir com muita evidência, quais foram os círculos que preservaram a tradição do êxodo: os campesinos; as mulheres (1,15ss; 2,1 e 15,20 ss) e os círculos proféticos". ${ }^{44}$

Em suma, a experiência de libertação da terra da escravidão configurou-se num paradigma. E no conjunto das "tradições vertero-testamentária, o êxodo veio ocupar lugar central. Tornou-se tradição teológica elementar, pois o êxodo testemunha a Javé Libertador" ${ }^{45} \mathrm{E}$ juntamente com a experiência no deserto do Sinai, formam outras tradições. "Fruto da tradição é a estreita

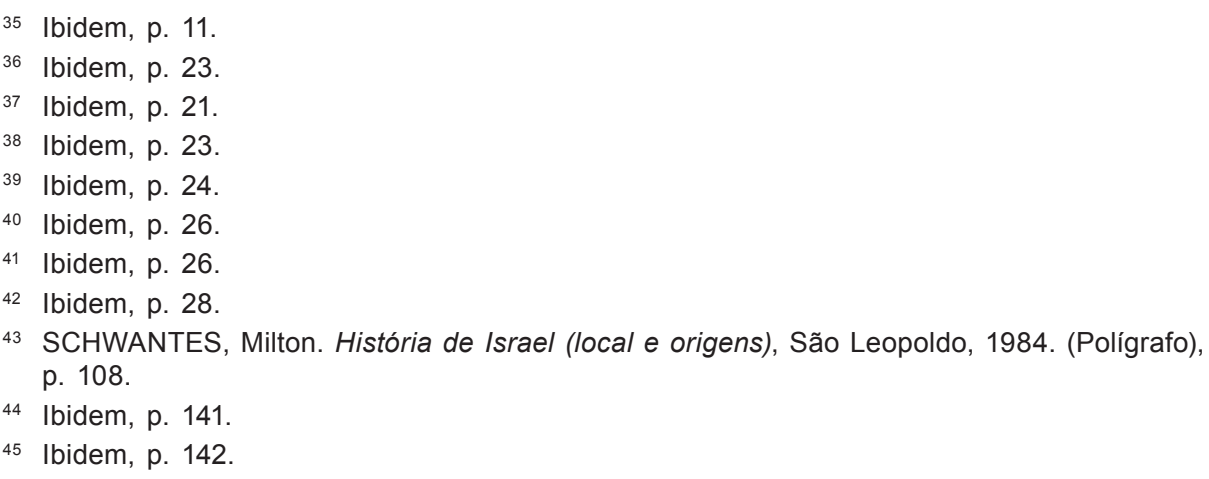


vinculação entre o êxodo e o Sinai. Quem saiu do Egito acampou no Sinai. ${ }^{46}$ No geral a tradição do êxodo dá sentido à do Sinai. ${ }^{47}$

\subsection{Deuteronômio como ápice e parte das Tradições do Êxodo}

No Livro do Deuteronômio encontramos o ápice da escuta. Agora, Israel, ouve os estatutos e mandamentos (Dt 4,1); eu os farei ouvir as minhas palavras (Dt 4,10); será que vocês já ouviram a voz de Deus? (Dt 4,33); escuta Israel (Dt 6,4); que se ouvires estes meus preceitos e praticares, o Senhor teu Deus. Guardará a aliança (Dt 7,12). Estes pedidos de Deus para escutá-lo é ao mesmo tempo um mandato, para que seu povo jamais se esqueça dos seus mandamentos e preceitos (Dt 4,1). Tal pedido para escutá-lo supõe uma atitude dócil e obediente à sua voz. É no Deuteronômio que encontramos a profissão de Fé dos Israelitas (Dt 6,4), ápice da revelação a um povo para que o escute. Portanto, o Livro do Deuteronômio, particularmente o "shema Israel", alcança o ponto mais alto da escuta. Cabe então focar no Shemá Israel, o que pode iluminar nosso estudo.

O "Shemá Israel" é parte do Deuteronômio e este do Pentateuco. Sua compreensão está ligada à compreensão deste Livro. Tal livro trata de temas essenciais para o povo de Israel, como: "a iniciativa da ação libertadora de Deus e a importância da Comunidade e da aliança”. ${ }^{48}$ Portanto, a consciência e o reconhecimento do povo à ação de Deus, dependem exclusivamente da atitude de escuta. Para que não esquecessem o que Deus realizou (libertação da terra da escravidão)! A ação libertadora de Deus torna-se um tema relevante porque a libertação é unicamente iniciativa de Deus. O Senhor Deus está à frente do seu povo, livrando-o de tudo o que lhe oprime. É um Deus Libertador. Este aspecto está vinculado à experiência do Êxodo (a experiência de libertação, da escravidão à liberdade). É a comunidade-povo de Israel o destinatário desta admoestação de Deus.

Deus é o Deus da aliança, que propõe um pacto com seu povo, para caminhar com seu povo, Israel. Revelando-Ihe seu plano, seu projeto de amor, que pede resposta. Levando em conta a história do Livro do Deuteronômio,

46 Ex 19,1.

47 Ibidem, 147. Ver também: Ex 20,2ss e Dt 6,20-33.

48 A Formação do Povo de Deus. Coleção Tua Palavra é Vida 2. São Paulo: Loyola, 1990, p. 77. 
não foi escrito de uma só vez, mas por longo tempo. Foi um longo tempo de transmissão oral, de geração em geração, e quanto a compilação destes textos assim nos diz: "começa no momento da conclusão da aliança, logo após a saída do Egito (1250 a.C.), até a entrada na terra prometida. E toda essa trajetória é explicitada na e pela boca de Moisés, em seus três discursos". 49

É necessário a atenção e o detalhe que o povo do reino do sul observou atentamente o que ocorrera no reino do norte (Israel), das "grandes crises porque passara aquele povo, seus irmãos: infidelidades, alianças ilegítimas com outros povos, abandono da aliança e enfim a destruição do reino do norte. Isso foi o pano de fundo da literatura do Deuteronômio. Após a queda da Samaria (capital do reino do norte), abrangendo o período do século VII até 566 a.C". ${ }^{50} \mathrm{E}$ após as densas crises por aquelas épocas, "alguns levitas emigraram para o sul (Reino de Judá), fixando-se em Jerusalém, levando consigo os escritos. Sendo encontrado por ocasião das reformas estabelecidas no tempo do rei Josias". ${ }^{51}$ Como o Reino do sul temia acontecer-Ihes o que ocorreu no reino do norte, criou-se oportunamente um ambiente favorável para o acolhimento, a aceitação e a propagação das reformas implementadas por Josias que a partir desses escritos valorizavam e retomavam a renovação da aliança e da fidelidade a Deus.

O Deuteronômio sempre foi um livro acima de tudo para o povo, que indicava o Amor de Deus ao seu Povo; o valor à vida como dom de Deus; e apontava para uma contínua renovação da aliança. São traços muito característicos que até no tempo presente lançam luzes e abrem horizontes, inclusive para nós cristãos deste século.

O "Shema Israel" como parte do conjunto do Livro do Deuteronômio, tornou-se Profissão de Fé antiquíssima dos judeus, que desde muito cedo, todo israelita reconhece e com o qual se identifica. A oração que o israelita justo e piedoso recita diariamente como verdadeira profissão de fé no Deus único e Verdadeiro. É a fidelidade a essa profissão de Fé que abre os ouvidos do povo e de cada um de seus filhos, que repetem várias vezes ao dia: "Escuta Israel! O Senhor nosso Deus é o Único Senhor" (Dt 6,4).

\footnotetext{
49 Ibidem, p. 77.

50 Ibidem, p. 78.

51 Ibidem, p. 79.
}

170 Revista de Cultura Teológica - v. 20 - N. 77 - JAN/MAR 2012 
A história dos "Judeus" 52 inicia-se com estas palavras do Senhor, para Abraão: "Vai para a terra que eu vou te mostrar [...] farei de ti uma grande nação [...] e em ti serão benditas todas as famílias da terra". ${ }^{53} \mathrm{E}$ mais tarde: "Seja íntegro e caminhe diante de Deus", são firmadas as bases do judaísmo: a promessa da posse de uma terra, a unidade do povo e o dever não apenas de pôr em prática a vontade de Deus e de ser íntegro, mas também de ser o arauto, caminhando diante dele para levar benção a toda à humanidade. Nesta benção está implícita a promessa da época messiânica, quando, sobre a terra, reinarão a paz e a harmonia porque todos os homens terão aceitado a palavra de Deus e porão em prática o amor e a justiça para com o próximo. Deus estabelece com Abraão uma Aliança, prometendo que não o abandonará, nem sua família nem sua descendência; uma Aliança que se perpetuará de geração em geração através do ato da circuncisão, sinal eterno de comunhão entre os judeus e Deus, sinal do pacto entre Deus e o seu povo. "Assim, Abraão deixa Ur, na Caldeia, para ir a uma terra desconhecida, a Terra de Canaã, habitada por outros povos, apoiado numa promessa que não prevê riquezas nem privilégios, mas que faz do povo judeu um povo escolhido por Deus para cumprir uma missão.

Depois de Abraão, Deus continua a realizar seu plano de Salvação através de seus descendentes, no cativeiro no Egito, age poderosamente libertando-os. Deus, em virtude da Aliança, vela sobre seu povo e o liberta da cruel escravidão e domínio do faraó. Envia Moisés para livrar seu povo da escravidão e, sobre o Monte Sinai, renova com ele a Aliança estabelecida já em Abraão. E todo o povo, num ímpeto de confiança, grita: "nós faremos o que Deus disse e obedeceremos". ${ }^{54}$ Então, Deus dá a Moisés a tábua da Lei, os mandamentos, que é sinal da Aliança.

A Profissão de Fé dos judeus (Shemá Israel) está inserida no tempo dessa história, da cultura e da vida desse Povo, Israel. Porque é Deus mesmo quem age e fala e um povo que acolhe e escuta. Portanto, o Shemá está "entre as primeiras palavras que a criança aprende de seus

\footnotetext{
52 Termo que designou originalmente as tribos de Judá e mais tarde os habitantes do reino de Judá e posteriormente referia-se a todo o povo de Israel.

53 Gn 12, 1-3.

54 Ex 24,7.
} 
pais" 55 e ainda mais: as "últimas que se murmura antes de morrer. Muitos judeus o recitaram silenciosamente ao entrar nas câmaras de gás. Eles testemunhavam que somente o Deus único tinha direito às suas vidas e que contra toda aparência nenhum outro poderia arrancá-las". ${ }^{56}$ Não há o exato momento em que se começou, como costume, a recitação do shemá Israel para o povo, mas é certo que nos últimos três séculos antes de Jesus, já era recitado diariamente.

Em hebraico, podemos transcrevê-lo para "Shem' yisrae' el". Em português, Shemá Israel é traduzido por "escuta Israel". O termo "escuta" refere-se à atitude de quem ouve. Já o termo "Israel" refere-se exatamente a um povo, aquele que escuta. A questão da "tradução" pode parecer irrelevante, mas por hora pode nos ajudar a compreender melhor sobre tantas traduções. Porém, a melhor tradução do Shemá Israel é mesmo a tradução da Escuta. Sobre essa questão remetemos a João Carlos de Almeida. ${ }^{57}$ Conclui-se que shema como ouvir está ainda bem limitado por causa das traduções. ${ }^{58}$ Devemos ampliar nossos horizontes, pois a tradução do Shemá para o português como nos fala João Carlos de Almeida ${ }^{59}$ é "pinçada" do dicionário Houaiss, que diz que ouvir é perceber pelo sentido da audição. Escutar seria estar consciente do que se está ouvindo. Alega que a tradução da Bíblia de Jerusalém não percebeu esta diferença e traduziu o Shemá Yisrael por ouve, ó Israel. Advoga que a tradução da $\operatorname{TEB}^{60}$ é mais precisa: escuta, ó Israel! O mesmo também alega que o termo usado nas traduções italianas é "ascolta" (escuta) e não sentire (ouvir). Para o sacerdote, Shemá certamente não quis significar ouvir uma voz. Por trás desse pensamento não pode estar incutida uma exegese equivocada, que não segue a tradição católica.

55 Retiro de abertura da assembleia da CNBB (abril/2008) realizada anualmente. Trecho da pregação de Dom Erwin. Itaíci, Indaiatuba/SP.

56 CARMINE Di Sante, Israel em Oração. As Origens da Liturgia Cristã, p. 65.

57 João Carlos de Almeida é Sacerdote da Congregação do Sagrado Coração de Jesus (SCJ). Um dos diretores da faculdade Dehoniana na Cidade de Taubaté/SP. Extraído em 15 de setembro de 2009. Autor: Leandro Martins de Jesus Fonte: http://www.veritatis.com. br/article/4861) que aborda esta questão, esclarecendo exatamente sobre tal.

58 "Ouve , ó Israel: lahweh nosso Deus é o 'único lahweh"'.

59 Nota acima, n. 30.

60 É a bíblia da Tradução Ecumênica Brasileira. 
Portanto, tal trecho "abre-se com um imperativo, ouça, seguido de vocativo, 'Israel'. ${ }^{61} \mathrm{Em}$ síntese é a atitude para que o povo escute Deus! Escutar somente a Deus, o único Deus! Configurando assim numa autentica confissão de Fé dos judeus. O Shemá Israel é a profissão de Fé do povo judeu. Nele, aparece a "confissão fundamental da fé em Israel". ${ }^{62}$ Sendo uma Confissão de Fé, torna-se singela oração em que "o judeu pronuncia várias vezes ao dia".

O "Shemá yi'srae' el" antes de tudo era rezado pelo povo Judeu antes mesmo de ser "escrita" e na época de Jesus, já era costume de todo judeu, recitá-la ao menos duas vezes ao dia, preferencialmente de manhã e de tarde como a escola do rabino Shammai ensinava. Porém, havia quem defendesse recitá-la a seu modo, como a escola de outro rabino, Hillel. ${ }^{63}$ Tudo isso nos faz pensar como o shemá Israel pode nos ajudar em nossa fé cristã. A partir dessa profissão de fé, pode nos orientar seguramente!

\section{JESUS COMO NOVO MOISÉS E MODELO DE ESCUTA}

O povo de Deus faz a experiência do êxodo e tal experiência torna-se um paradigma. Por isso, encontramos Jesus, no Novo Testamento, como a figura do Cristo, o novo Moisés. ${ }^{64}$ No Novo Testamento, Jesus faz "a

61 LOPES, Felix Garcia. O Pentateuco. Navarra/Espanha: editorial verbo divino, 2011, p. 92.

62 Nota n. 30. Ambos eram dois grandes mestres do judaísmo pré-cristão e viveram no reinado de Herodes o Grande, p. 64.

63 Nota, 30. Ambos eram dois grandes mestres do judaísmo pré-cristão e viveram no reinado de Herodes o Grande, p. 64.

64 Bíblia Peregrino, p. 2317. Há um bom comentário neste sentido do Cristo como novo Moisés. Apresenta Jesus como antítipo de Moisés e superior a ele até. Podemos ver a infância de Jesus (Mt 1 e 2). Também em Mateus, Jesus recomenda os mandamentos da lei judaica; e os corrige, propondo "bem-aventuranças" acrescentando: "pois eu vos digo". A comunidade de Mateus não deve ter saudade do passado nem renegá-lo. Agora se aglutinam em sua lealdade a Jesus, Messias e Mestre, novo Moisés e filho de Davi; Ao longo deste texto mesmo, será citado vários autores que reconhecem o Cristo, especialmente o Cristo do Evangelho de Mateus, como o novo Moisés; No Dicionário Enciclopédico da Bíblia, p. 956-957. Encontramos outro razoável comentário: Em Mateus, há provas de que sua intenção era de apresentar os ensinamentos de Jesus, agrupados em 5 discursos, como um novo Pentateuco. E como Moisés é tido como o autor do Pentateuco, então Jesus se equipara. Outro comentário sobre o Jesus como novo Moisés está em: FERNANDES, L. A. A Bíblia e sua mensagem. Rio de Janeiro: Editora Puc-Rio, 2010, p. 118. Este comentário diz "que no Evangelho de Mateus, o Messias é esperado pelo povo judeu, prometido pela Lei e nas Profecias". Para confirmar este fato, este evangelho utiliza, abundantemente, o AT 
trajetória que o povo do Antigo Testamento fez ao descer do Egito e de lá regressar". 65 "Noutro momento vemos um Jesus que se transfigura lá no alto da montanha (novamente lembrando Moisés), e lá tem como testemunhas seus discípulos". 66

O Jesus como novo Moisés, especialmente a partir do evangelho de Mateus nos recorda vivamente a figura de Moisés. Quando Jesus se depara em conflito com a Lei do Sábado, por exemplo. Quando Jesus insiste na prática dos mandamentos, sobretudo quando diz sobre o maior dos mandamentos da Lei (Mt 22,36). Insiste na síntese e na primazia de dois mandamentos sobre todos os demais: "Amarás o Senhor teu Deus, com todo o teu coração, com toda a tua vida e com toda a tua mente. Este é o maior e o primeiro mandamento. O segundo é semelhante: amarás o teu próximo como a ti mesmo. Destes dois mandamentos dependem toda a Lei e os Profetas" (Mt 22,37-40). Faz-nos recordar de Moisés, mestre da Lei, quando instrui sobre normas e leis e se depara em tensão com os peritos da lei: impuros (Mt 9,11), sobre o jejum (Mt 9,14). Mas acima de tudo quando Jesus está no alto da montanha e dali faz seu discurso chamado sermão da montanha: (Mt 5,21.27.31.33.38.43). Jesus também remetia com certa veemência à lei de Moisés e Ihe dá sua interpretação: "ouvistes o que foi dito [...], porém, eu vos digo" (Mt 5,21).

Como o novo Moisés, Jesus com frequência vai à montanha para orar, para o encontro com Deus (Ex 4,27; Mt 14,23). Desce para instruir o povo (Ex 32,15; Mt Mt 5,1). Não é demasiado afirmar Jesus como novo Moisés e também como verdadeiro modelo de escuta. No breve tempo de seu ministério e de forma inequívoca, expressa a importância da escuta, ainda que não tenha explicitamente verbalizado tal vontade. Entretanto, deixa claro seu descontentamento pelo modo como se vive a fé em Israel, pelos desvios cometidos pelos fariseus e os mestres da lei, dos excessos de normas infligidas ao povo. Diversas vezes Jesus manifesta, mesmo que implicitamente, a intenção de resgatar a fé de Israel.

e o seu conteúdo são articulados em função do anúncio de Jesus como Messias. Mateus, ao colocar por escrito as palavras e ações de Jesus, parece ter levado em consideração o Pentateuco, a pessoa de Moisés e a liturgia sinagogal.

65 SCHWANTES, M. História de Israel (local e origens). São Leopoldo, 1984, p. 108. (Polígrafo) Cf. Mt 2.

66 SCHWANTES, Milton (et alii). A memória popular do Êxodo. Petrópolis: Vozes, 1988, p. 7. (Estudos Bíblicos, n. 16). 
Jesus não quis transgredir as normas vigentes do seu tempo, do seu povo, mas resgatar o que estava adormecido, meio que morto, sem vigor, desfigurado! Por isso, orienta seus ouvintes para não se iludirem nem pensarem que viria abolir ou dar fim às leis vigentes. Sua intenção era dar novo vigor, ou retomar o que já tinha sido esquecido. Não criou nova lei, mas a partir do que existia deu um sabor diferente, talvez, resgatando seu principio, sua origem. E, portanto, como a escuta era vital para o povo de Israel, assim o foi também para Jesus.

Os fariseus tinham uma nobre função: ensinar o povo a guardar e preservar as tradições e as leis dadas por Deus a Moisés desde sua origem. No decorrer do tempo foram acrescentando uma série de normas, acumulando-se e tornando-se demasiadamente rigorosa e legalista. Ao povo caberia praticá-las, mas os fariseus se eximiam de vivê-las. Jesus falava de "carga pesada" (Mt 23,4), que eles mesmos não viviam, mas cobravam do povo simples e humilde que as praticasse. Por isso a exortação de Jesus: "sigam o que eles vos falam, mas não façais o que eles fazem" (Mt 32,3). Há indícios que na época de Jesus havia mais de 600 preceitos a serem praticados cuidadosamente, como por exemplo, lavar as mãos antes das refeições e 365 preceitos de proibições e 248 preceitos de mandamentos.

Jesus como autêntico judeu, buscou viver originalmente sua fé. Não exatamente criar coisas novas, criar uma fé nova, adorar outro Deus. A diferença entre Jesus e os demais líderes religiosos estava na "forma" de transmitir o ensinamento. A diferença do ensinamento de Jesus não estava tanto no seu conteúdo, estava profundamente enraizada no Primeiro Testamento, mas na sua maneira de ensinar. Ele não dependia das autoridades, como faziam os escribas, mas falava a partir da sua própria experiência de Deus, do Deus da vida, que em seu tempo estava ofuscado por tantas leis e discussões legalistas e teológicas. Os ouvintes de Jesus diziam que era um "novo ensinamento, dado com autoridade" (Mc 1,21-28). É tão real essa preocupação de Jesus que ele resumiu todos esses preceitos em apenas dois dizendo: "façam aos outros aquilo que você quer que vos façam. Essa é Lei e os Profetas" (Mt 7,12). Ou ainda, em um momento de embate com o grupo dos saduceus, que não creem na ressurreição, Jesus recorda o Deus dos pais, Abraão, Isaque, Jacó, calando-os! E aos fariseus, depois que thes pergunta qual é o preceito mais importante, afirma que o mais importante dos preceitos é "amarás o Senhor teu Deus de todo teu coração e o segundo e equivalente ao anterior é: "amarás teu próximo como a ti mesmo" 
(Mt 22,36-40). Jesus não quis, portanto, abolir nada, mas dar o devido lugar valor ao que é essencial para a fé, nada mais que isso.

Identificamos em Jesus aquele que por excelência estava à escuta do Pai. Não é demais lembrar as vezes que Jesus deixava tudo e se colocava em colóquio com seu Pai. Era ali no silêncio, que Jesus se colocava inteiramente à escuta. Levava para Deus suas experiências do dia e o que estava no íntimo do seu coração e as apresentava ao Pai. A atitude de Jesus era mesmo a de Escutar o Senhor Deus. E não poderia ser diferente, após o dia de intensos trabalhos. Não podia ser outra a atitude de Jesus a não ser a de escuta. Estar ali silenciosamente diante de Deus, escutando-o. O dia tão repleto de vozes, de insinuações, de ruídos que causam distração e desvia dos caminhos de Deus. É somente resgatando a escuta de Deus, que podemos compreender o sentido e significado das nossas vidas.

O Shema Israel nos diz antes de tudo, escutar Deus. E Jesus nos ensina isto com sua vida, seu exemplo, isto é, ser ouvinte dócil de Deus. Devemos considerar que se Jesus gostava de estar a sós com Deus, em que consistiria seu colóquio com Deus: falava, cantava, pedia? Qual era a matéria ${ }^{67}$ da qual Jesus se ocupava no tempo de sua "intimidade" com Deus? Ousamos dizer que Jesus fazia desse tempo um momento de colóquio com Deus para escutá-lo! A Escuta de Deus era o que "preenchia" esse momento. É através da escuta de Deus, que Jesus compreendeu sua vontade. É pela "escuta da Palavra de Deus" que compreendeu sua missão. Numa sinagoga, após escutar a proclamação da Palavra de Deus do Profeta Isaías, toma consciência de sua missão (Lc 4,17-21). Sua Mãe, Maria, promete ser a serva da Palavra porque a escutava com docilidade. Jesus valoriza a atitude de outra Maria, irmã de Marta, quando se põe atentamente a escutar sua Palavra, deixando tudo, seus afazeres domésticos, para escutá-lo (LC 10,38-42).

No Primeiro Testamento escutar é escutar a Deus. No segundo Testamento, escutar é basicamente escutar a Jesus. Basicamente a fé depende da escuta do Senhor Jesus, da escuta de sua Palavra, que sai de sua boca, porque também Ele, Jesus, escutava seu Pai. Mateus nos remete ao pedido de Deus-Pai para que escute seu Filho, Jesus. É uma afirmação do próprio

${ }^{67}$ Quando falo matéria, é o conteúdo que constitui ou o que existe efetivamente. Não se pode imaginar a oração de Jesus sem "nada"!

176 Revista de Cultura Teológica - v. 20 - N. 77 - JAN/MAR 2012 
Deus que expressa: "Este é o meu Filho amado, o meu predileto. Escutai-o" (Mt 17,5). Lucas compreende da mesma forma esse mistério: "da nuvem veio uma voz, que dizia: Este é meu Filho escolhido: Escutai-o" (Lc 9,35). Tanto Mateus como Lucas testemunham a importância da escuta para a fé. Todo o segundo Testamento reconhece, afirmando categoricamente que até mesmo a fé depende da escuta: "pelo ouvido, ouvindo a mensagem do Messias" (Rm 10,17).

Pela escuta se obtém a fé, pela escuta se descobre o seguimento de Jesus. No quarto evangelho encontramos o testemunho que diz que os primeiros discípulos de Jesus seguiram-no depois de escutar a pregação de João Batista: "No dia seguinte, João Batista estava com dois de seus discípulos. Vendo Jesus passar, diz: aí está o Cordeiro de Deus. Os discípulos o ouviram e seguiram Jesus" (Jo 1,35-38). A escuta tornou-se essencial para nossa fé, na medida em que é essencial para nossa salvação. O próprio Cristo atesta e confirma quando fala que é "pela escuta e a fé na sua Palavra que se alcançará a vida eterna" (Jo 5,24). E "até os mortos terão semelhante atitude de ouvir o Senhor na ressurreição" (Jo 5,28). Ainda mais, até as ovelhas que não pertencem a seu redil também terão tal capacidade de "escutá-lo". ${ }^{68}$ E aqueles que são as ovelhas do redil, saberão escutá-lo! Pelas palavras de Jesus compreendemos que somente "quem escuta Deus Pai irá até Jesus" (Jo 6,45-46).

Há também coisas que escutamos que é bastante difícil de escutar, é duro! Porque às vezes o que escutamos nem sempre nos agrada. Se nos colocamos numa atitude sincera de escuta a Deus, não devemos esperar escutar só o que nos agrada, mas acima de tudo o que Deus quer. Quando nos colocamos à escuta de Deus, Ele fala, convoca e envia! Assim foi para os "ouvintes de Jesus" 69 que se queixaram aos discípulos, considerando serem muito duras as suas palavras, porque para segui-las deveriam "comer sua carne e tomar seu sangue" (Jo 6,53-58). Eis literalmente a queixa dos seus ouvintes: "Muitos dos discípulos que o ouviram comentavam: "Esse discurso é bem duro: quem poderá escutá-lo"? (Jo 6,59).

68 Jesus tem plena consciência de sua missão: "Tenho outras ovelhas que não pertencem a esse redil; a essas tenho que guiar, para que escutem minha voz". Jo 10,16.

69 Queremos dar agora ao termo "ouvinte", uma conotação negativa, enfatizando ouvinte como aquele (a) que apenas usa os ouvidos para ouvir, nada mais! 
É devido às "exigências" no seguimento do Senhor que muitas vezes resistimos em não escutá-lo. Com isso nos fechamos em nós mesmos. É o que ocorre em nossa cultura com os "excessos" de barulho, ruídos ou até em nossas orações, porque multiplicando palavras, ocupamos nosso interior com aquilo que nos desvia de Deus. Ocupamos o tempo demais com palavras humanas mais que à escuta silenciosa de Deus, para que fiquemos presos em nossas próprias palavras e não na voz de Deus. Pedro, no seu veemente discurso diante dos "responsáveis" do templo diz: aos sacerdotes e comissários do templo, afirmando uma realidade decisiva na vida da Comunidade primitiva: ouvir a Deus ou ouvir aos homens? Quando as palavras humanas se opõem à Palavra de Deus, não nos resta dúvida: "Parece justo a Deus que obedeçamos a vós antes que a Ele? Julgai-o. Quanto a nós, não podemos calar o que sabemos e ouvimos" (At 4,18b).

Estamos diante de uma radical verdade da fé: quem não escuta a Palavra de Deus não vem de Deus. "aquele que vem de Deus escuta as palavras de Deus. Por isso vós não escutais, porque não procedeis de Deus" (Jo 8,47). Encontramos aqui um mistério insondável: escutar Deus.

\section{CONCLUSÃO}

A conclusão é o reconhecimento da relevância da escuta para a fé cristã, já que a escuta é o ato privilegiado quando nos relacionamos com Deus. Quando nos encontramos diante do mistério que se revela. Evidentemente nos calamos diante do mistério que se revela, de sua Palavra que se apresenta. Quando está presente sua voz nos calamos para escutar a Palavra de Deus. Palavra de Deus que nos interpela, nos convida, tratando-nos como amigos ${ }^{70}$ e busca aliança conosco. ${ }^{71} \mathrm{E}$ se quisermos perseverar nos caminhos da fé, teremos que aprender inevitavelmente a escutar. Mais do que meros "ouvintes", somos chamados a escutar. Escutar evidentemente a Palavra de Deus que nos interpela no mundo de hoje e nos provoca. Se quisermos perseverar no caminho da Fé, devemos, antes de tudo, ser homens e mulheres que escutam.

70 Ex 33,11. Ver também na Dei Verbum, n. 2.

71 Ex 24,8. Ver também na Dei Verbum, n. 14.

178 Revista de Cultura Teológica - v. 20 - N. 77 - JAN/MAR 2012 
Por causa da fé no Senhor, devemos agir assim, humildemente, à escuta de sua Palavra como Marta (Lc 10,38-41) e à luz do exemplo do Mestre Jesus nos colocar também à escuta do ser humano. Quanto à isso, é evidente que se quisermos transmitir ao mundo algo que seja significante, devemos primeiro nos colocar à escuta do próprio ser humano, como Jesus. No Evangelho percebemos nitidamente a atitude de Jesus que escuta os pobres, os pecadores, as pessoas que lhe procuravam. E se a escuta é relevante para a fé em Cristo como mencionamos, também o é na relação com os nossos semelhantes. Cabe a nós então, (re) descobrir esse mistério tão presente na vida de cada um, na nossa vida. E como um todo é "afetado" quando simplesmente escutamos.

\section{BIBLIOGRAFIA}

ALONSO Schokel, Luis (dir.). Concilio Vaticano II: comentarios a la constitución Dei Verbum sobre la divina revelación. Madrid: BAC, 1969.

ANJOS, Gonzalo Tejerina (coord.). Vaticano II. Acontecimiento y recepción. Estudios sobre El Vaticano II a los cuarenta años de su clausura. Universidad Pontifícia de Salamanca, 2006.

CARMINE Di Sante, Israel em Oração. As Origens da Liturgia Cristã. São Paulo: Paulinas, 1989.

CEGALLA, Domingos Paschoal. Nova Minigramática da Língua Portuguesa. 3. ed. São Paulo: Companhia Editora Nacional, 2008.

CUNHA, Celso Ferreira da. Gramática da Língua Portuguesa. Rio de Janeiro: FAE, 1992.

DOCUMENTOS do Concílio Ecumênico Vaticano II. São Paulo: Paulus, 2004.

FABRIS, Rinaldo (org.). Problemas e Perspectivas das Ciências Bíblicas. São Paulo: Loyola, 1993.

FERNANDES, Leonardo Agostini. A Bíblia e a sua mensagem. Introdução à leitura e ao estudo da bíblia. Rio de Janeiro: PUC - Editora/Editora Reflexão, 2011. FERNANDES, Leonardo Agostini; GRENZER, Mathias. Exxodo 15,22-18,27. São Paulo: Paulinas, 2011. (Comentário Bíblico Paulinas).

FORMAÇÃO DO POVO DE DEUS. Coleção Tua Palavra é Vida 2. 1990.

KLOPPENBURG, Boaventura. Concílio Vaticano II. Vol. II. Primeira Sessão (set/ Dez. 1962), Petrópolis, Vozes, 1963.

LATOURELLE, René. Teologia da Revelação. São Paulo: Paulinas, 1981. 
LÉON-DUFOUR, Xavier (dir). In: Vocabulário de Teologia Bíblica. Petrópolis: Vozes, 2005.

LIBANIO, João Batista. Concilio vaticano II. Em busca de uma primeira Compreensão. São Paulo: Loyola, 2005.

LOPES, Felix Garcia. O Pentateuco. Navarra/Espanha: Editorial Verbo Divino, 2011, p. 92.

PAULO VI, Papa. Constituição Dogmática Dei Verbum sobre a Revelação Divina. In: Documentos do Concílio Ecumênico Vaticano II (1962-1965). 4. ed. São Paulo: Paulus, 2007.

PIAZZA, Waldomiro O. A revelação cristã: na constituição dogmática "Dei Verbum". São Paulo: Loyola, 1986.

SCHWANTES, Milton (et alii). A memória popular do Êxodo. Petrópolis: Vozes, 1988. (Estudos Bíblicos, n. 16).

História de Israel (local e origens). São Leopoldo, 1984. (Polígrafo).

180 Revista de Cultura Teológica - v. 20 - N. 77 - JAN/MAR 2012 